\title{
MULTIVARIATE ANALYSIS OF THVERARTINDUR CLINOPYROXENES, SE ICELAND
}

\author{
Alvar SOESOO
}

Geoloogia Instituut (Institute of Geology), Estonia pst. 7, EE-0001 Tallinn, Eesti (Estonia)

Tartu Ülikooli geoloogia instituut (Institute of Geology, University of Tartu), Vanemuise 46, EE-2400 Tartu, Eesti (Estonia)

Presented by V. Puura

Received 2 January 1996, accepted 3 June 1996

Abstract. The Tertiary Thverartindur volcanic complex in SE Iceland constitutes a plutonic formation of ultramafic, olivine- and quartz-tholeiitic, hybrid rock types, and granophyres. Mafic rocks, representing very slightly modified magmatic compositions, consist mainly of plagioclase and clinopyroxene (CPX), whereas CPX is the solidus phase. A specific feature of Thverartindur CPXs is the lack of distinctive zoning, exsolutions of lamellae or blebs, and compositional overlap by En, Fs, and Wo values. By applying the principal component analysis the interelement relationship of the chemical composition of CPXs has been investigated. Summarizing the results of the analyses we may note a distinct separation of $\mathrm{Fe}$ from $\mathrm{Mg}$ and $\mathrm{Ca}$, while slight $\mathrm{Fe}$-enrichment as a process, is observed only in quartz-tholeiitic gabbros. The CPXs crystallized at high temperature reveal the substitution of $(\mathrm{Na}+\mathrm{Al}+\mathrm{Si}) \leftrightarrow(\mathrm{Ti}+\mathrm{Ca}+\mathrm{Mg})$ while at low temperature (quartz-tholeiites) $\mathrm{Na}$ replaces $\mathrm{Ca}$ towards slight $\mathrm{Fe}$-enrichment. The $(\mathrm{Na}+\mathrm{Al}) \leftrightarrow(\mathrm{Ti}+\mathrm{Ca}+\mathrm{Mg})$ substitution against a $\mathrm{Mg} \#$ decrease seems to be widespread in CPXs from the more evolved gabbros. Two different hybrid rock types are distinguished based on the CPX interelement relationship. A good negative correlation between $\mathrm{Na}$ and $\mathrm{Ca}$, and their positive correlation with $\mathrm{Mg}$ indicates that the $\mathrm{Na} \leftrightarrow \mathrm{Ca}$ substitution occurs commonly in "hybrid CPXs" and is associated with a $\mathrm{Mg}$ decrease in CPXs. Unfortunately, quantifying the magnitude of late- and postmagmatic exchange reactions is impossible by this method because: (i) the genuine criteria allowing the distinction of purely magmatic and postmagmatic processes are lacking; (ii) not all mineral grains analysed have been modified by later reactions.

Key words: clinopyroxene composition, principal component analysis, plutonic rocks, Iceland.

\section{INTRODUCTION}

The Tertiary Thverartindur volcanic formation in SE Iceland provides a good plutonic section over a large chemical variability of rocks such as ultramafics, olivine- and quartz-tholeiites, hybrid rocks, and granophyres. 
Mafic rocks, occurring as sills and sheets of very slightly modified magmatic compositions, consist mainly of plagioclase and clinopyroxene (CPX), whereas CPX is the solidus phase. A specific feature of Thverartindur CPXs is the lack of distinctive zoning, exsolutions of lamellae or blebs, and compositional overlap of En, Fs, and Wo values in spite of different initial magma compositions. Thus, a different approach is needed to determine the characteristics of CPXs crystallizing from various magmas in a complicated oceanic spreading environment. Detailed geology and petrology of this complex can be obtained from Annels (1967), Newman (1967), Bromann \& Soesoo (1994), and Soesoo (1995a, 1995b). CPX chemistry and crystallization conditions are treated by Soesoo (in press). The aim of the present study is to describe and evaluate the interelement relationship of CPX constituents within the Thverartindur hybrid-mafic-ultramafic rock types by applying the principal component analysis. Based upon multivariate statistics, the elements likely to subordinate to magmatic and postmagmatic substitutions, are presented.

\section{MATERIAL AND METHODS}

More than $300 \mathrm{CPX}$ microprobe analyses have been made from the Thverartindur plutonics. The analyses were performed on an ARL-SEMQ instrument at Nordic Volcanological Institute, Reykjavik, Iceland. The analytical conditions were: beam potential $15 \mathrm{kV}$, current $80 \mathrm{nA}$, and the counting times of $10 \mathrm{~s}$ for peak and $4 \mathrm{~s}$ for the background. For multivariate statistics $201 \mathrm{CPX}$ core analyses were selected in order to investigate the intersample and -element relationship and to evaluate possible magmatic and postmagmatic exchange reactions.

The multivariate statistical analysis is a powerful tool for petrological and petrogenetical purposes, since petrology and geochemistry deal with multistructural data arrays which do not have simple properties like the common-sense two- or three-dimensional space arrangement. One of the best known multivariate methods is the principal component analysis. The application of the principal component analysis in geology has been well described and analysed by many authors (e.g. Le Maitre, 1982; Till \& Colley, 1973; Marriott, 1974). Therefore only brief comments are given here.

The principal component analysis is a mathematical technique for reducing the number of original variables into a new set of variables called principal component (PC) coordinates which contain a decreasing amount of variance and are not correlated with each other. Usually, the first two or three PCs account for a sufficiently high proportion of variance so that other components may be dismissed. In an idealized case, every component will be interpreted as a process(es). The method defines the 
new orthogonal axes called eigenvectors, which are in principle the direction of maximum spread of the original data in terms of the $\mathrm{N}$ dimensional space. In the present case nine variables were considered $-\mathrm{Si}$, $\mathrm{Ti}, \mathrm{Al}, \mathrm{Cr}, \mathrm{Fe}, \mathrm{Mn}, \mathrm{Mg}, \mathrm{Ca}$, and $\mathrm{Na}$ oxides, forming a 9-dimensional space and gaining the characteristics of a closed data array.

Eigenvectors can be calculated either from a variance-covariance matrix or from a correlation matrix. The choice of the input matrix is highly dependent on the original data and the petrologic task. Le Maitre (1982) has discussed the choice of a matrix type. Although the original data were measured on the same scale ( $w t \%)$, it is considered reasonable to use a correlation matrix for extracting the eigenvectors. This approach gives the same weight for every element in the CPX composition. The magnitude of major and minor elements will for example reach as high as 5200 for the pair $\mathrm{SiO}_{2}-\mathrm{Cr}_{2} \mathrm{O}_{3}$. Using the correlation matrix, the weight of the elements is standardized into the range $[-1 \ldots 1]$. Thus, each element acts in correlative relation to each other and a "superpositional" influence arising from the total (wt\%) magnitude can be neglected.

\section{RESULTS}

\section{Principal component analysis of individual clinopyroxene compositions}

The interelement relationship of $\mathrm{CPXs}$ from the Thverartindur ultramafic, olivine-, and quartz-tholeiitic plutonic rocks is variable in spite of their rather similar major element chemical compositions. Below a summary of the results obtained through the principal component analysis is given.

Normalized factor values of each analysis in the multivariate space (first two PCs) show a distinct grouping for CPXs from the olivinetholeiitic, quartz-tholeiitic, ultramafic rocks, and one hybrid sample (Fig. 1). The geometry of the fields, corresponding to rock types, is probably related to the initial magma chemistry and to the process responsible for the crystallization, in some cases to the subsolidus and postmagmatic reaction features.

Pyroxenes from ultramafic rocks. The augites from the Thverartindur ultramafic dyke, sill, and xenoliths occupy two fields separating the samples of xenolith and sheet origin. If the ultramafic rock unit represents the cumulative phase of a single magmatic lineage, which is very likely controlled by similar magmatic processes, they may occupy a common field in a two-PC space. However, this is not seen in Fig. 1 showing a different magmatic origin of these samples. 


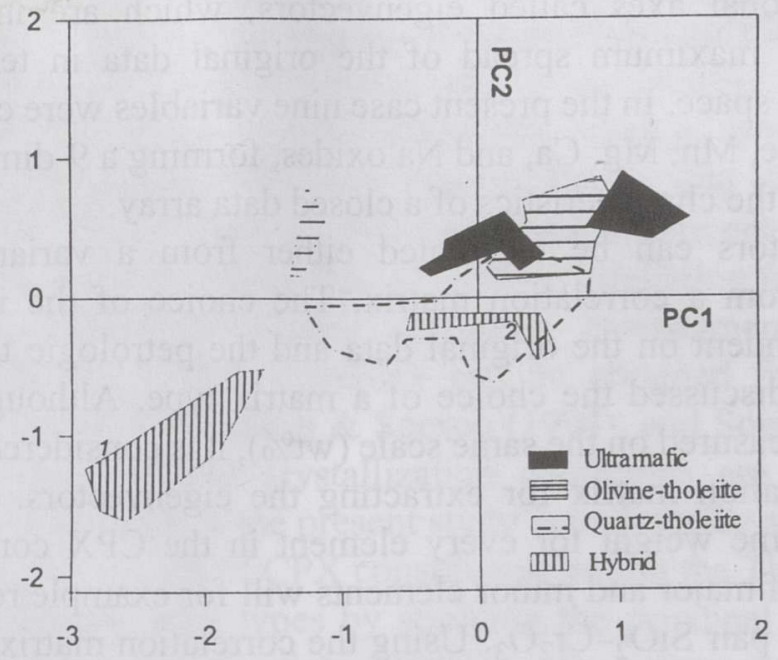

Fig. 1. Intersample relationship of Thverartindur clinopyroxenes (CPX) in the two principal component (PC1, PC2) coordinates. Separation of CPXs with distinctive initial magma chemistry and late- and postmagmatic processes is evident, in spite of convergent En, Fs, and Wo values.

1,2 - hybrid rock types.

The first two PCs (PC1, PC2) account for $78 \%$ of variance. Ca has the highest positive loading with PC1 (Fig. $2 a$ ). Fe and $\mathrm{Mg}$ are negatively correlated to $\mathrm{Ca}$, but show also a high and negative loading to PC1 indicating that this component describes the $\mathrm{Ca} \leftrightarrow(\mathrm{Fe}+\mathrm{Mg})$ relationship/ substitution. Relying upon the covariance and principal component analysis, three processes would be suggested. (i) An inversion of the primary orthopyroxene and/or pigeonite into CPX. This is supported by the occurrence of some remnant orthopyroxene cores inside CPX crystals and by the negative correlation between $\mathrm{Ca}$ and $\mathrm{Mg}, \mathrm{Fe}$, and $\mathrm{Si}$ ( $\mathrm{Si}$ decreases) following this substitution. (ii) $\mathrm{Fe} \leftrightarrow \mathrm{Mg}$ substitution, particularly Fe increases. This can be interpreted as the ferro-augite factor. (iii) Later Na-enrichment, obviously caused by subsolvus reaction where $\mathrm{Na}+\mathrm{Si}$ substitute $\mathrm{Mg}$ and $\mathrm{Ca}$, with an emphasize on $\mathrm{Ca}$ in further $\mathrm{Fe}$-enrichment. The involvement of $\mathrm{Mg}$ in later substitution is also expressed by approximated standard deviations from the first three PCs, which are for $\mathrm{Mg} 0.64,0.78$, and 0.95 , respectively.

CPXs from olivine-tholeiitic gabbros. CPXs occupy a slightly elongated field in Fig. 1 and show mainly $\mathrm{Ca}-\mathrm{Fe}$ variation. Four CPXs from one sample have rather different parameters and plot on separate fields with high $\mathrm{Mg}-\mathrm{Na}-\mathrm{Al}$ dispersion (left in Fig. 1). In terms of the chemical composition, this indicates an extraordinarily high $\mathrm{Al}, \mathrm{Na}$, and $\mathrm{Fe}$ content of these CPXs in contrast to much lower $\mathrm{Mg}$ and $\mathrm{Ca}$. This may be explained by crystallization or reaction with a trapped more evolved liquid. 
The first two PCs account for 65 and $15 \%$ of total variance, respectively. However, the approximated standard deviations for $\mathrm{Mg}, \mathrm{Fe}$, and $\mathrm{Ca}$ are 87, 93, and 86 (from 100), respectively in case of the first component, while the second component adds $7 \%$ for $\mathrm{Ca}$. Consequently, the processes and changes of chemical constituents of CPXs of olivinetholeiitic rocks can be fairly adequately described by the first two PCs. The dominant variation in the loading plot (Fig. 2b) is a distinct separation of $\mathrm{Fe}$ and $\mathrm{Si}$ versus all other elements. It should be emphasized that $\mathrm{Fe}$ has negative correlation with all other major and trace elements in contrast to the ultramafic rocks where $\mathrm{Fe}$ and $\mathrm{Mg}$ have positive correlations (Fig. $2 a, b$ ). $\mathrm{Si}$ and $\mathrm{Na}+\mathrm{Al}$ have a high loading for the second $\mathrm{PC}$, which indicates a possible $(\mathrm{Na}+\mathrm{Al}+\mathrm{Si}) \leftrightarrow(\mathrm{Ti}+\mathrm{Ca}+\mathrm{Mg})$ substitution.
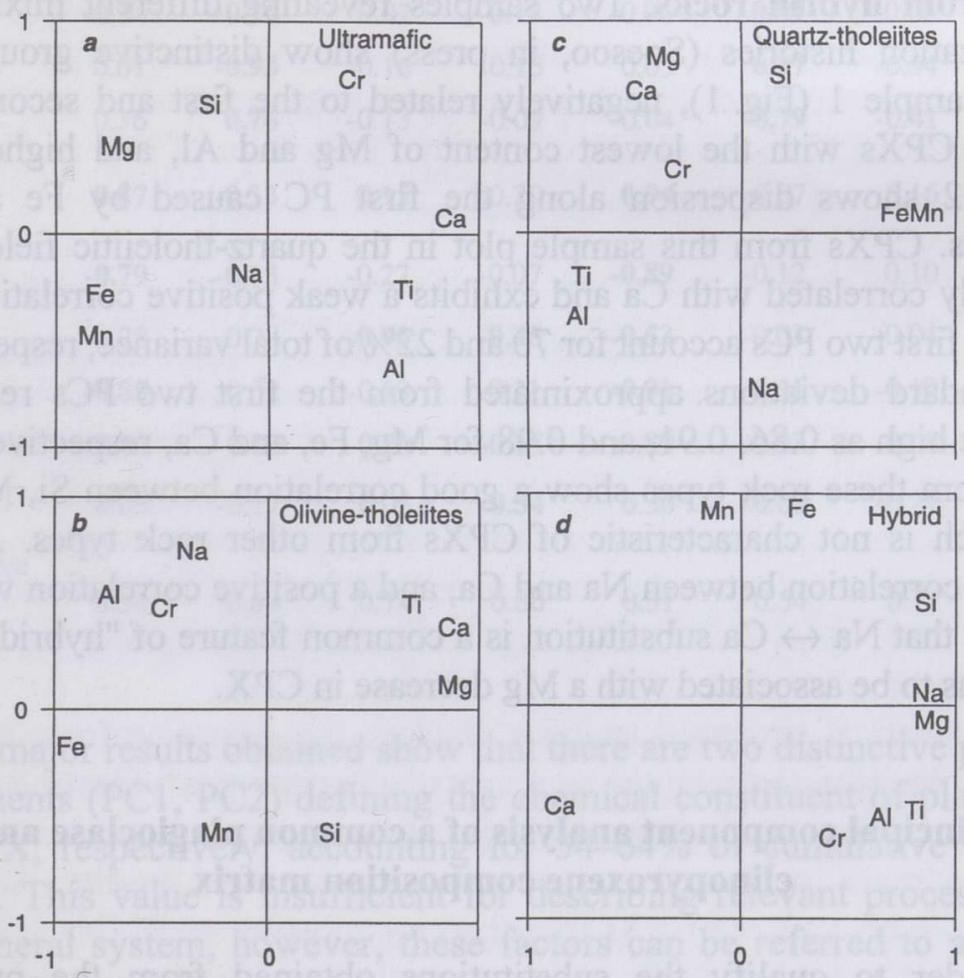

Fig. 2. Principal components 1 and 2 (PC1, PC2) score plot of 201 clinopyroxene (CPX) analyses from the Thverartindur plutonic formation. Ultramafic $(a)$, olivine-tholeiitic gabbros $(b)$, quartztholeiitic gabbros $(c)$, and hybrid rocks $(d)$ have been considered.

CPXs from quartz-tholeiitic gabbros. The CPXs from the quartztholeiitic gabbros occupy an elongated field along the first PC and show a relatively low dispersion against the second PC (Fig. 2c). A good covariation is observed between $\mathrm{Ti}$ and $\mathrm{Al}$. Fe exhibits a weak negative 
correlation with $\mathrm{Mg}$ and $\mathrm{Ca},-0.33$ and -0.39 , respectively. The first two PCs account for 56 and $20 \%$ of variance, the third PC adds $8 \%$. Standard deviations for $\mathrm{Mg}, \mathrm{Fe}$, and $\mathrm{Ca}$, approximated from the first three $\mathrm{PCs}$, are 82,87 , and 77 , respectively. This comparatively low value indicates that the chemical evolution of main CPX constituents cannot be entirely described by $2-3 \mathrm{PCs}$, in spite of the appropriate value of relative loading of $84 \%$ (three PCs). Thus, the history of CPXs from the quartz-tholeiitic gabbros is more complex than that of the olivine-tholeiitic CPXs. Higher $\mathrm{Na}$ activity compared to the ultramafic and olivine-tholeiitic rocks is observed, which is not surprising in more evolved tholeiitic magma(s). Na is negatively correlated with $\mathrm{Mg}, \mathrm{Ca}$, and $\mathrm{Si}$ (Fig. $2 c$ ), showing possible substitution $(\mathrm{Mg}, \mathrm{Ca}) \leftrightarrow \mathrm{Na}$ with slight influence on Fe.

CPXs from hybrid rocks. Two samples revealing different mixing and crystallization histories (Soesoo, in press) show distinctive grouping in Fig. 1. Sample 1 (Fig. 1), negatively related to the first and second PCs, contains CPXs with the lowest content of $\mathrm{Mg}$ and $\mathrm{Al}$, and highest $\mathrm{Mn}$. Sample 2 shows dispersion along the first PC caused by $\mathrm{Fe}$ and $\mathrm{Ca}$ variations. CPXs from this sample plot in the quartz-tholeiitic field. $\mathrm{Fe}$ is negatively correlated with $\mathrm{Ca}$ and exhibits a weak positive correlation with $\mathrm{Mg}$. The first two PCs account for 70 and $22 \%$ of total variance, respectively. The standard deviations approximated from the first two PCs reach the values as high as $0.86,0.91$, and 0.98 for $\mathrm{Mg}, \mathrm{Fe}$, and $\mathrm{Ca}$, respectively. The CPXs from these rock types show a good correlation between $\mathrm{Si}, \mathrm{Mg}$, and $\mathrm{Na}$, which is not characteristic of CPXs from other rock types. A good negative correlation between $\mathrm{Na}$ and $\mathrm{Ca}$, and a positive correlation with $\mathrm{Mg}$ indicates that $\mathrm{Na} \leftrightarrow \mathrm{Ca}$ substitution is a common feature of "hybrid CPXs" and seems to be associated with a Mg decrease in CPX.

\section{Principal component analysis of a common plagioclase and clinopyroxene composition matrix}

In order to qualify the substitutions obtained from the principal component analysis of CPX compositions, an attempt was made to juxtapose two predominant minerals, plagioclase and CPX, in the Thverartindur olivine- and quartz-tholeiitic gabbros. Altogether, 78 chemical analyses of plagioclase and CPX from six samples were considered by applying multivariate statistics. Six major elements from both minerals were selected for the input matrix (see Table). Assuming ideal exchange reactions (i.e. all mineral grains analysed have exchanged chemical elements) between these minerals, there might be a strong correlation between the elements involved into reaction. 
Normalized factor loadings (principal components; PC1-PC4) computed from the correlation matrix using 78 chemical analyses of Thverartindur plagioclases (PL) and clinopyroxenes (CPX). Significant loadings (bold) indicate elements which are involved into a certain principal component, later interpreted as a process. 2D geometrical image of element relationship can be obtained by plotting principal components against each other

\begin{tabular}{|c|c|c|c|c|c|c|c|c|}
\hline \multirow{3}{*}{ Elements } & \multicolumn{8}{|c|}{ Plagioclases and clinopyroxenes } \\
\hline & \multicolumn{4}{|c|}{ From olivine-tholeiites } & \multicolumn{4}{|c|}{ From quartz-tholeiites } \\
\hline & $\mathrm{PC} 1$ & $\mathrm{PC} 2$ & PC3 & PC4 & $\mathrm{PC} 1$ & $\mathrm{PC} 2$ & $\mathrm{PC} 3$ & PC4 \\
\hline $\mathrm{SiO}_{2}^{\mathrm{CPX}}$ & -0.52 & 0.12 & 0.69 & -0.32 & -0.20 & 0.71 & 0.52 & 0.14 \\
\hline $\mathrm{Al}_{2} \mathrm{O}_{3}^{\mathrm{CPX}}$ & 0.44 & 0.72 & -0.18 & 0.09 & 0.10 & 0.11 & -0.80 & -0.39 \\
\hline $\mathrm{FeO}^{\mathrm{CPX}}$ & 0.18 & 0.94 & -0.05 & -0.20 & -0.08 & -0.26 & 0.88 & -0.14 \\
\hline $\mathrm{MgO}^{\mathrm{CPX}}$ & -0.34 & -0.76 & 0.02 & -0.18 & -0.06 & 0.89 & -0.08 & 0.16 \\
\hline $\mathrm{CaO}^{\mathrm{CPX}}$ & 0.01 & -0.93 & -0.16 & 0.15 & 0.05 & 0.87 & -0.34 & -0.10 \\
\hline $\mathrm{Na}_{2} \mathrm{O}^{\mathrm{CPX}}$ & 0.36 & 0.76 & -0.13 & -0.09 & -0.04 & -0.79 & -0.41 & 0.11 \\
\hline $\mathrm{SiO}_{2}^{\mathrm{PL}}$ & 0.87 & -0.33 & 0.15 & -0.20 & 0.94 & 0.07 & 0.16 & -0.08 \\
\hline $\mathrm{Al}_{2} \mathrm{O}_{3}^{\mathrm{PL}}$ & -0.79 & -0.13 & -0.27 & -0.07 & -0.89 & -0.12 & 0.10 & -0.11 \\
\hline $\mathrm{FeO}^{\mathrm{PL}}$ & 0.28 & -0.28 & -0.70 & -0.45 & -0.53 & -0.03 & -0.04 & -0.04 \\
\hline $\mathrm{CaO}^{\mathrm{PL}}$ & -0.85 & 0.32 & -0.19 & 0.21 & -0.91 & 0.11 & -0.19 & -0.02 \\
\hline $\mathrm{Na}_{2} \mathrm{O}^{\mathrm{PL}}$ & 0.89 & -0.32 & 0.20 & -0.15 & 0.89 & 0.03 & 0.08 & -0.33 \\
\hline $\mathrm{K}_{2} \mathrm{O}^{\mathrm{PL}}$ & 0.65 & -0.17 & 0.03 & 0.54 & 0.36 & -0.08 & -0.21 & 0.87 \\
\hline $\begin{array}{l}\text { Cumulative } \\
\text { loadings }\end{array}$ & 0.34 & 0.64 & 0.74 & 0.80 & 0.31 & 0.54 & 0.71 & 0.80 \\
\hline
\end{tabular}

The major results obtained show that there are two distinctive principal components ( $\mathrm{PC} 1, \mathrm{PC} 2)$ defining the chemical constituent of plagioclase and CPX, respectively, accounting for $54-64 \%$ of cumulative variance (Table). This value is insufficient for describing relevant processes in a two-mineral system, however, these factors can be referred to as "pure" mineral factors. The third and the fourth factor add about $20 \%$ of cumulative loading and may be referred to as secondary alteration including possible exchange reactions. The analysis of normalized factor loadings (Table) shows slight differences in the interaction of "olivineand quartz-tholeiitic" plagioclase and pyroxene. As noted above, sodium and occasionally iron play an important role in more evolved gabbros (quartz-tholeiites), whereas olivine-tholeiitic gabbros exhibit a range of processes affected by $\mathrm{Al}, \mathrm{Ca}$, and $\mathrm{Si}$. Thus, the possible substitutions on the base of CPX compositions, as stated above, are pertinent also to analysing two major mineral systems. 
Unfortunately, the method applied does not allow of quantifying the magnitude of exchange reactions because: (i) genuine criteria for distinguishing purely magmatic and postmagmatic processes are lacking; (ii) not all mineral grains analysed have been modified by later reactions; (iii) the raw data matrix (chemical analyses) does not satisfy specific statistical requirements for a more detailed study. Therefore, the data of present mineral-pair statistical analysis can be treated as an additional proof of the results obtained from the individual CPX statistical analysis. The magnitude of a certain element exchange can be quantified if mineral pairs are treated as a closed system, and accordingly, the statistically representative amount of analyses is available.

Because of the lack of genuine criteria allowing us to distinguish between purely magmatic and postmagmatic processes in terms of minor chemical changes in plagioclase and pyroxene compositions, the results of the present study may have suffered from the misinterpretation of contemporary processes involved, but not from qualitative evaluations. Also, involving the third phase, oxides, the behaviour of iron and titanium can be considered more precisely.

\section{CONCLUSIONS}

Summarizing statistical analyses of the Thverartindur CPX constituents, it can be concluded that $\mathrm{Fe}$ is distinctly separated from $\mathrm{Mg}$ and $\mathrm{Ca}$, while the slight $\mathrm{Fe}$-enrichment as a process is evident only in quartz-tholeiitic gabbros. Fe-enrichment, which is a common trend for layered and unlayered mafic intrusions, is not observed within Thverartindur plutonics.

The statistical structural analysis displays Si separation from all other elements in olivine-tholeiites and negative relation of $\mathrm{Ca}$ to all other elements within hybrid rocks. Na separation in quartz-tholeiites shows a regular increase in $\mathrm{Na}$ activity towards more evolved basalts. At higher temperature crystallized CPXs reveal major substitution of $(\mathrm{Na}+\mathrm{Al}+\mathrm{Si})$ $\leftrightarrow \quad(\mathrm{Ti}+\mathrm{Ca}+\mathrm{Mg}$ ), while at lower temperature (quartz-tholeiites) $\mathrm{Na}$ replaces $\mathrm{Ca}$ towards slight but continuous Fe-enrichment. The $\mathrm{Na} \leftrightarrow \mathrm{Ca}$ substitution against total $\mathrm{Mg}$ decrease seems to be a common feature of CPXs from the more evolved basaltic rocks.

Two different hybrid rock types can be distinguished by the CPX composition, particularly by the interelement relationship in CPX. Unfortunately, quantifying the magnitude of late- and postmagmatic exchange reactions is still impossible by this method because: (i) there are no genuine criteria allowing the distinction of purely magmatic and postmagmatic processes; (ii) not all mineral grains analysed have been modified by later reactions. 
The principal component analysis is a productive method in the study of CPXs from diverse rock types in different geological environments, particularly in the investigation of "hidden" processes and geochemical structures.

\section{ACKNOWLEDGEMENTS}

The present article is a part of the project undertaken at Nordic Volcanological Institute, Iceland. I would like to thank the staff of this institute for the help with analyses.

\section{REFERENCES}

Annels, A. E. 1967. The Geology of the Hornafjordur Region. PhD Thesis, University of London. Bromann, M. \& Soesoo, A. 1994. Structure and petrology of a central volcanic complex in SE Iceland. (Abstract). Journal of Icelandic Geological Society, 29-30.

Le Maitre, R. W. 1982. Numerical Petrology; Statistical Interpretation of Geochemical Data. Elsevier, Amsterdam.

Marriott, F. H. C. 1974. The Interpretation of Multiple Observations. Academic Press, London.

Newman, T. C. M. 1967. The Geology of Some Igneous Intrusions in the Hornafjordur Region, S.E. Iceland. $\mathrm{PhD}$ Thesis, Victoria University of Manchester.

Soesoo, A. 1995a. Petrology and Petrogenesis of the Thverartindur Plutonic Formation, SE Iceland. Open File Report. Nordic Volcanological Institute, Reykjavik.

Soesoo, A. 1995b. Diversity of plutonic rocks in the oceanic crust: The Thverartindur central volcanic complex, SE Iceland. Proc. Estonian Acad. Sci. Geol., 44, 4, $234-248$.

Soesoo, A. Clinopyroxenes from a plutonic formation of the Icelandic central volcano. Proc. Estonian Acad.Sci. Geol. (in press).

Till, R. \& Colley, H. 1973. Thoughts on the use of principal component analysis in petrogenetic problems. J. Int. Assoc. Math. Geol., 5, 341-350.

\section{THVERARTINDURI (KAGU-ISLAND) KLINOPÜROKSEENIDE MULTIVARIATSIOONILINE ANALÜÜS}

\section{Alvar SOESOO}

Tertsiaarse vanusega Thverartinduri vulkaaniline kompleks Islandil pakub läbilõike ultraaluselistest kuni happelistest plutoonilistest kivimitest. Aluselised kivimid koosnevad peamiselt plagioklassist ja hiliselt kristalliseerunud homogeensest või vähetsonaalsest klinopürokseenist, kusjuures erinevate kivimitüüpide pürokseenid kattuvad En-Fs-Wo arvude põhjal. Põhikomponentide analüüsiga on tuvastatud, et primitiivsemate gabrode klinopürokseenidele on iseloomulik $(\mathrm{Na}+\mathrm{Al}+\mathrm{Si}) \leftrightarrow(\mathrm{Ti}+\mathrm{Ca}+\mathrm{Mg})$ asendumine, kusjuures kvarts-toleiitsetes gabrodes naatrium asendab kaltsiumi. Nimetatud analüüs lubab klinopürokseeni koostise alusel eristada kahte hübriidsete kivimite tüüpi. 


\title{
МУЛЬТИВАРИАЦИОННЫЙ АНАЛИЗ КЛИНОПИРОКСЕНОВ ТВЕРАРТИНДУРСКОГО КОМПЛЕКСА, ЮГО-ВОСТОЧНАЯ ИСЛАНДИЯ
}

\author{
Алвар СОЕСОО
}

Тверартиндурский комплекс третичного возраста сложен разными по составу породами - от ультраосновных до кислых. Основные породы представлены большей частью плагиоклазом и позднекристаллическим слабозональным или гомогенным клинопироксеном, причем пироксены из пород различного типа совпадают по числу En, Fs и Wo. Мультивариационный анализ основных компонентов показал, что для клинопироксенов из примитивных габбро характерно замещение $(\mathrm{Na}+\mathrm{Al}+\mathrm{Si}) \leftrightarrow(\mathrm{Ti}+\mathrm{Ca}+\mathrm{Mg})$, а для клинопироксенов из кварц-толеитных габбро - замещение натрия кальцием. По этому признаку два типа гибридных пород хорошо различимы между собой. 